\title{
Croatia - the path from Yugoslavia to the EU Future: success or wash-out?
}

\section{Tamás Borbély}

Debreceni Egyetem Kerpely Kálmán Doktori Iskola, Debrecen

borbelyreporter@gmail.com

\section{SUMMARY}

Croatia joined to the European Union as the $28^{\text {th }}$ member state on June the $1^{\text {th }} 2013$. With this it became the second ex-yugoslavian country to be part of the European elite. Croatia's long road from being part of a socialist state conglomerate to become the newest member of the EU was not just winding but often and still it is shaky.

Keywords: Croatia, Balkans, EU, economy

\section{ÖSSZEFOGLALÁS}

2013. június elsején Horvátország 28. tagként csatlakozott az Európai Unióhoz. Ezzel a második volt Jugoszláv tagállamává vált az európai elitnek. Horvátország hosszú útja a szocialista államföderalizmusból az EU tagságig nem csak kanyargós, de gyakran ingatag is volt és jelenleg is az.

Kulcsszavak: Horvátország, Balkán, EU, gazdaság

\section{INTRODUCTION}

\section{Historical review}

To understand our southern neighbor's past year and a half or so we need to know the historical prefaces of the country also. The formation of Yugoslavia in 1945 was pre-ordainedly a fall as most or all the union of federal countries that were united violently or mightily by higher, dominant power. After the second world war more than half of the Croatian population were yokels so the economy was traditionally settled as an agricultural and stock-raising economic society. The so-called violent industrialisation was started and organized by the socialist state in the 1950s. During the 50s and 60s Yugoslavia introduced market socialism which came together with price liberalization and the integration into the capitalist world economy. That came from Tito's loss of confidence in the USSR. Tito's liaison with socialism although did not suffer from any confidence at all. Decentralization arrived in 1965 which caused growth in different sectors such as turism. The income of the Croatian industry was spent for the development of the poorer regions of Yugoslavia. With this Croatia had to put down for once and always that it payed more money into the joint account than it ever get from it (Table 1). Among others this factor had led to the unrest between the two most developed Yugoslavian states Slovenia and Croatia and the Federal People's Republic of Yugoslavia and also this strenghtened the national movements. Among others it also led to the proclamation of independence of these two member states and finally to the patriotic war (Druzic, 2010).

GDP within the state of the Former Yugoslavia

\begin{tabular}{lccc}
\hline \multicolumn{2}{c}{ Republic } & & \multicolumn{2}{c}{ Economy } \\
\hline Slovenia & Number of inhabitants & GDP/USD million & GDP/USD per capita \\
Croatia & 1982000 & 13740 & 6940 \\
Serbia & 4784000 & 25640 & 5350 \\
Vojvodina & 9534000 & 27930 & 2930 \\
Mid-Serbia & 1996000 & 7660 & 3380 \\
Kosovo & 5582000 & 16910 & 3030 \\
Bosnia and Hercegovina & 1956000 & 3360 & 1770 \\
Montenegro & 4364000 & 10870 & 2490 \\
Macedonia & 652000 & 1520 & 2330 \\
T Yugoslavia & 2021000 & 4420 & 2180 \\
\hline
\end{tabular}

Source: IMF/World Bank (1990) 


\section{MATERIALS AND METHODS}

\section{Croatia after the patriotic war}

In the first half of the 1990's the military spendings grew brutally which in 1994 had transcended 60 percent of all the governmental spendings. From a relatively unprepared country which characterized Croatia militaryily in 1991 became a de facto wartime economy.
In 1991, 1992 the most important sector which was turism, that meant all seashores of the Croatian Adria was almost fully destroyed caused by the fights with the Serbian separatists. Also economy as a whole was destroyed. By proclaiming independence Croatia lost almost all of its previous markets and GDP started to freefall rapidly. Just in 1994, 1995 could Gross Domestic Product arise by a minimal amount. In 1994 by 0.6 percent, in 1995 by 1.7 percent (Table 2).

Damages caused by the war

\begin{tabular}{lrrr}
\hline & \multicolumn{1}{c}{ HRK } & USD & Structure \\
\hline Material damage & 95202202 & 14968899 & 40.2 \\
Costs of war and asset non-maintenance & 61675982 & 9697481 & 26.1 \\
Human life and health & 79553384 & 12508393 & 33.7 \\
Total & 236431568 & 37174774 & 100.0 \\
\hline
\end{tabular}

Source: The Government of Republic of Croatia (1999)

\section{Independence and the road to Europe}

Between 1994 and 2007 Croatian consolidated budget could produce sufficit only twice. In 1994 and in 1998. Besides the two mentioned years between 1994 and 2000 a trending budgetary deficit growth characterized the economy which culminated in 2000 when it became as high as 5 percent of the GDP (Nikic, 2003). The state debt of Croatia between 1994 and 2007 from 19.4 billion kunas raised to 130.9 billion which meant a 6.7 times bigger margin and in GDP ratio it meant that from the 22.2 percent in 1994 it raised to 52.6 by 2005 (CNB, 2006). The external debt from 754 million kuna in 1994 grew to 50 billion by 2004 that is 67 times larger than it was previously. The growth of the external debt until 1997 was caused by re-timing of the inherited external debt liabilities. These were inherited from Yugoslavia (Central Bureau of Statistics, 1991-2007).

\section{Effects of the crisis}

As for almost all of the countries in the Balkans Croatia faced with the world economy crisis much later than the European countries but correlating to its size and strength it caused more damage. In 2008 growth had ,only” split in half, in 2009 GDP went negative moreover in the first quarter in the year by more then 6.7 percent which was enourmous even in an environment hit by crisis. Besides the crisis the weak performace was caused by the structural problems also. On these problems the economic policy orchestrated by the government did not help either because it was based only on fiscal austerity measures on the state financing which was meant to reduce budget deficit (Figure 1). Unemployment raised significantly also by 2009 . By the first half of the year it was 1.8 percent higher than a year before. It was prominent because in the previous years unemployment showed a much better picture because of the seasonal employment possibilities. This was because of the crisis not enough anymore to compensate the the losses of jobs and because of the recession at turism and building industry lesser seasonal job opportunities were generated. In 2010 there was a 17.6, in 2011 a 17.9 percent unemployment rate was traced.
Figure 1: Gross government debt as \% of GDP

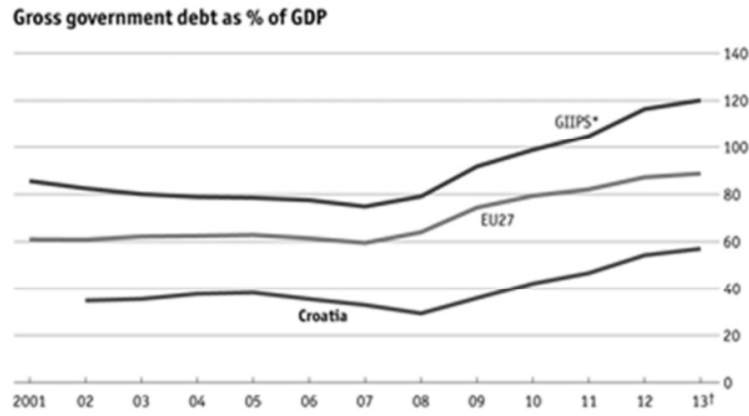

Source: World Bank (2014)

While in 2009 the economy growth was -6 percent, in 2010 it became -1.2 and in 2011 it seemed that the Croatian economy was thru the bad times. The 2011 account turned into positive and it almost reached 1 percent. If we see the datas of the budget deficit it does not shows us a positive picture. While in 2008 deficit was -0.9 according to GDP, in 2009 it became -3.1 , in $2010-4.6$ and in 2011 around -6 percent was the deficit the Croatian economy had to face with. The growth of the budget deficit is still, currently growing in Croatia (Borbély, 2011).

\section{Somewhere in Europe}

After 10 years of waiting on July the $1^{\text {st }} 2013$ Croatia finally became a full member of the European Union. It became the second ex-Yugoslavian countries after Slovenia to join. On the economy map of the EU the Croatian economy shows similarity to the so-called GIIPS countries. GIIPS often called Mediterranean countries although the abbreviations stands for Greece, Ireland, Italy, Portugal and Spain. The high 17-19 percent unemployment rate, the 52 percent youth unemployment shows much similarity with the countries that are stinted and helped over and over by the EU. From 2008 the Croatian economy shrinked 13 percent, the analysts waited a one percent growth for 2013, but that did not arrive either. Namely it did but with a negative signal (World Bank, 2014). 
On the economic angle there is not much to be happy about when it comes to the Croatian accession to the EU. With the eye of the EU that is struggling with serious economic problems just another troubled country joined to the community while to Zagreb the economic benefits of the accession and the membership will only appear couple of years later. And also Croatia had to face with the fact that almost minutes after or the next day of the accession ceremony the EU had started an Excessive Deficit Procedure (EDP) on the country that resulted newer and newer austerity measures.

Although the accession results news foundings and the confidence of investors will grow as an EU member the country have to face with new challenges. Just like in Hungary's case right after the accession an EDP was started on the counrty because since 2009 every year Zagreb exceeded the 3 percent budget deficit ordained by Brussels and according to the present forecasts it will continue this year and in the following year also. EDP will cause austerity measure from the social-democrat government.

\section{After the accession}

Enthusiasm had dwindled within the Croatian population about the EU. It fell from the 200480 percent to its half by the time of the accession and most of the people are afraid that the accession will not or could not bring any improvment short and mid-term. On certain fields Croatia had changed on its own profit. The operability of the state improved in the last couple of years for example. But according to the newest surveys corruption had forced back and the legal system started to become EU compatible.

Croatia had steped into the sixth year of recession in 2014 according to the World Bank with a half percent negative growth. As I mentioned before in 2013 the annual growth was -0.9 percent and it was caused by the continuing fall of consumption, setback of investments and also the weak export.

As I mentioned above in the first half of 2014 GDP fall continued although manufactoring and export started to grow. The continuing GDP fall caused the growth of unemployment and it culminated on the record high 18.8 percent int he first half of 2014. At the same time the July employment datas showed a pick-up which was caused by the seasonal jobs. The youth unemployment is on a EU high 50 percent. Debt has rose to the 67 percent of GDP in 2013 while external debt rose to 105 percent. Croatia continued the fiscal consolidation that was ordered by the European Commission because of the EDP. Governmental deficit eased from the 5 percent in 2012 to 4.9 in 2013 and it eased further 2.1 percent by July of 2014. However consolidated governmental debt was 69.5 percent by May of 2014 which means 13 percent growth according to the 2012 data (Figure 2).

According to the European Commission within the EDP the deficit of Croatia must be abated to 4.6, 3.5 and 2.7 percent in 2014, 2015 and 2016. The Commission had recognized the Croatia made efficient steps in reforms but it appropriated further steps on the field of public foundings, tax policy, pension and welfare system, health, education and employment.
Figure 2: Government budget balance as of \% of GDP

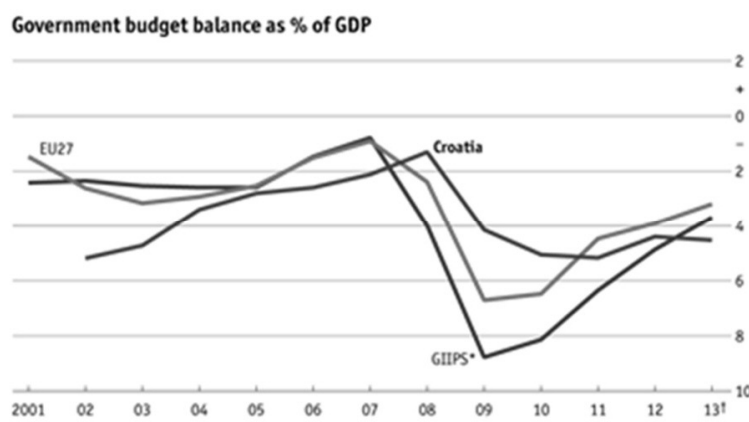

Source: World Bank (2014)

\section{RESULT}

\section{What future brings}

World Bank forecasts slow growth in 2015. The optimistic scenarios says the export to the Euro Zone will start to grow, private investments starts to grow also and the privatisation of the state owned companies and EU founds will push economy further. The structural reforms started by the government on the field of employment, pension and welfare and investments will go with job creation, production growth and social cohesion although in a short term almost none of these will be visible (Table 3).

Table 3

Macro indicators

\begin{tabular}{lrrrr}
\hline & 2011 & 2012 & 2013 & 2014 \\
\hline GDP growth \% & 0.0 & -2.2 & 0.3 & 1.7 \\
Industrial production \% & -1.3 & -8.0 & 0.2 & 2.2 \\
Budget balance \% GDP & -4.5 & -3.5 & -4.0 & -3.9 \\
Inflation \% & 2.0 & 4.7 & 3.9 & 3.0 \\
Import (billion dollars) & 22.4 & 20.4 & 21.0 & 21.5 \\
Export (billion dollars) & 13.6 & 12.2 & 12.3 & 12.4 \\
Debt \% of GDP & 101.9 & 104.1 & 105.4 & 105.9 \\
\hline
\end{tabular}

Source: World Bank (2014)

\section{CONCLUSION}

When we talk about Croatia's future there are lots of questions and possibilities. Significantly influences the picture of what will happen to INA. Because it is not just the biggest companies in Croatia but also it generates the most profits, and payes the most taxes but it also gives employment to a lot of people. Also very significant the question of energy dependence. Since Nabucco is stalled and Russia anounced that it stops Southern Stream just days ago there are lots of question that are raised on the field of energy dependence and also employment as a whole.

Future is influenced also by the free movement of labour. It has long traditions in Croatia. During socialism in the time of Yugoslavia there was a time when not less than 400000 Croatians were working abroad. During that time they transfered most of their or part of their wages to Yugoslavia. In the future, within the EU it will not happen, so the budget will not receive the amount of foreign accounts as it received in the 70's 
and 80's. Also the EU, and the labour market of the EU can be and will be attractive to the Croatians mostly for the youth who are speaking languages and also well educated. Another important matter in accordance to Croatia's future is the access of EU funds and the usuage of them. As a new country it can also give the fundamental of the country's future in the Union. Tax policies, austerity measures and other economic policies can determine the future of Croatia not just because of stability but the possibility to get rid of EDP and get access to more cohesion funds. Very important question is what is going to happen with agriculture and industry. As the market opened Croatia had to deal with enourmous challenges. Agriculture as a matter of fact can be on the losing side of EU because as it is traceable almost all of the countries that had joined the EU suffered agriculturally because of the prices and possibilities. The EU subventions are not as high as it is for the previously joined countries that raises prices for the products while because of the single market products from all over the EU will reach Croatia. Most of these products are cheaper because of the subventions. So agriculture and industry might lose market position on its own field, in its own country (World Bank, 2014).

Is it good to be part of the EU or not? Good or at least it is better to be in than outside of it. Is it good for Croatia to be part of the EU that question can only be answered years later. Is it good for the EU that Croatia became part of it? On one hand it is. On the other hand not really. Just another economy in bad shape. The positive and negative effects on Croatia in and from the EU will only be visible a couple of years from now.

The effects of the accession to the EU are hardly visible now but in my $\mathrm{PhD}$ thesis I will point out how and why did not only Croatian but the other ex-Yugoslavian countries' economic policy had changed between 1945 and 2017, from where did they come from to where did they get. Who as a full member of the EU, who as joint partners, who as antechambers and who as totally hopeless.

\section{REFERENCES}

Druzic, G. (2010): Razvoj poduzetnistva u Hrvatskoj, u: Restrukturiranje gospodarstva u Hrvatskoj. Book 3. Faculty of Economics and Business. Zagreb. 51-59.

Nikic, G. (2003): Tranzicija u Hrvatskoj - Deset godina stabilnosti tecaja i cijena. Binoza Press. Faculty of Economics and Business. Zagreb

Central Bureau of Statistics (1991-2007). Statistical Yearbooks. Zagreb.
CNB (2006): Croatian National Bank (1996-2014): Annual Reports. Zagreb.

The Government of Republic of Croatia (1999): State Commission for War Damage Assessment. Final Report. Zagreb.

Borbély T. (2011): Horvátország gazdaságpolitikai integrációja az Európai Unióba.

World Bank (2014): Croatia Snapshot 2014. http://www.worldbank. org/content/dam/Worldbank/document/eca/Croatia-Snapshot. pdf 